\title{
Pengaruh Tingkat Kecemasan Terhadap Kualitas Tidur Ibu Hamil Trimester Tiga Di Puskesmas Tanjung Karang Mataram
}

\author{
Siti Annisa Rahmasita1, ${ }^{1}$ gustine Mahardika², Muhammad Rizkinov Jumsa ${ }^{3}$ \\ 1. Program Studi Pendidikan Dokter, Fakultas Kedokteran, Universitas Mataram, Mataram, Indonesia \\ 2. Staf Pengajar, Bagian Kedokteran Jiwa, Fakultas Kedokteran, Universitas Mataram, Mataram, Indonesia \\ 3. Staf Pengajar, Bagian Obstetri dan Ginekologi, Fakultas Kedokteran, Universitas Mataram, Mataram, \\ Indonesia
}

\begin{abstract}
ABSTRAK
Pendahuluan: Kecemasan merupakan keadaan patologis yang ditandai dengan gejala fisiologis dan gejala psikologis, gejala-gejala tersebut dapat terjadi berbeda pada setiap orang dan situasi. Pada kehamilan, risiko terjadinya kecemasan akan meningkat. Memasuki trimester tiga, ibu hamil dapat merasa cemas akan keselamatan dirinya maupun keselamatan bayinya. Saat merasa cemas, akan terjadi peningkatan kadar noradrenergik akibat stimulasi sistem saraf simpatis yang akan menyebabkan berkurangnya siklus rapid eye movement (REM), sehingga meningkatkan frekuensi terbangun di malam hari dan menyebabkan kualitas tidur yang buruk. Kecemasan dapat menurunkan kadar gamma amino-butyric acid (GABA) sehingga seseorang akan sulit untuk menginisiasi tidur. Penelitian ini bertujuan untuk melihat pengaruh tingkat kecemasan terhadap kualitas tidur ibu hamil trimester tiga.

Metode: Desain penelitian ini adalah deskriptif analitik dengan pendekatan cross sectional. Jumlah responden pada penelitian ini adalah sebanyak 32 ibu hamil trimester tiga di Puskesmas tanjung Karang Mataram, dengan teknik consecutive sampling. Alat pengambilan data pada penelitian ini adalah kuesioner Hamilton Anxiety Rating Scale (HARS) untuk mengukur tingkat kecemasan dan kuesioner Pittsburgh Sleep Quality Index (PSQI) untuk mengukur kualitas tidur. Data pada penelitian ini dianalisis menggunakan uji korelasi Spearman.

Hasil dan Pembahasan: Penelitian menyatakan bahwa tingkat kecemasan berpengaruh terhadap kualitas tidur ibu hamil trimester tiga di Puskesmas Tanjung Karang Mataram dengan $\mathrm{P}$ value $<0,001$ (P value < $0.5)$ dan $r=0.731$ menunjukkan korelasi positif dengan kekuatan korelasi yang kuat.
\end{abstract}

Kesimpulan: Tingkat kecemasan berpengaruh terhadap kualitas tidur ibu hamil trimester tiga di Puskesmas Tanjung Karang Mataram.

Kata Kunci: Kehamilan; Kualitas Tidur; Trimester Tiga; Tingkat Kecemasan

\begin{abstract}
Introduction: Anxiety is a pathological condition characterized by physiological and psychological symptoms, these symptoms can occur differently in each person and situation. In pregnancy, the risk of anxiety will increase. Entering the third trimester, pregnant women can feel anxious about their safety and the safety of their babies. While feeling anxious, there will be an increase in noradrenergic levels due to stimulation of the sympathetic nervous system which will cause a decrease in REM cycles, thereby increasing the frequency of waking at night and causing poor sleep quality. Anxiety can lower GABA levels so the person will have difficulty initiating sleep.

Methods: The design of this research is descriptive analytic with a cross sectional approach. The number of respondents in this study were 32 third trimester pregnant women at Tanjung Karang Mataram Public Health Center, with consecutive sampling techniques. Data collection tools in this study were the Hamilton Anxiety Rating Scale (HARS) and the Pittsburgh Sleep Quality Index (PSQI). The data in this study were analyzed using the Spearman correlation test.

Results and discussions: The study stated that the level of anxiety affects the sleep quality of third trimester pregnant women at the Tanjung Karang Mataram Health Center with P value <0.001 (P value <0.5) and $r=0.731$ indicating a positive correlation with a strong correlation strength.
\end{abstract}

Correspondence: Siti Annisa Rahmasita, Universitas Mataram, Email : srahmasita@gmail.com 
Conclusion: The level of anxiety affects the sleep quality of third trimester pregnant women at Tanjung Karang Public Health Center Mataram.

\section{Keywords: Pregnancy; Sleep Quality; Third Trimester; Anxiety Levels}

\section{PENDAHULUAN}

Kehamilan merupakan sebuah proses pertumbuhan bayi di dalam rahim seorang ibu ${ }^{1}$. Kehamilan diawali dengan proses fertilisasi ovum dan spermatozoa, kemudian dilanjutkan dengan implantasi di dinding uterus. Kehamilan dibagi menjadi tiga trimester, yaitu trimester pertama (sejak konsepsi hingga minggu ke-12), trimester kedua (minggu ke-13 hingga minggu ke-27), dan trimester ketiga (minggu ke-28 hingga minggu ke-40) ${ }^{2}$. Ibu mengalami berbagai perubahan penting dalam hidupnya, seperti pengalaman menstruasi pertama, kehamilan, dan bahkan menopause. Kehamilan merupakan salah satu tahap kehidupan yang sangat penting dalam kehidupan seorang ibu. Ibu dapat mengalami berbagai perubahan dalam tubuhnya, baik secara fisik maupun psikologis dan sosial ${ }^{3}$.

Kecemasan merupakan gangguan kesehatan mental yang paling umum ${ }^{4}$. Kecemasan adalah keadaan patologis yang ditandai dengan gejala fisiologis (seperti gemetar, berkeringat, dan detak jantung meningkat) dan gejala psikologis (seperti panik, tegang, bingung, dan tidak dapat berkonsentrasi). Gejala-gejala tersebut dapat berbeda pada setiap orang dan situasi ${ }^{5}$. Pada kehamilan, risiko terjadinya kecemasan akan meningkat ${ }^{6}$. Memasuki trimester ketiga, ibu hamil akan mempersiapkan dirinya untuk menyambut peran serta tanggung jawab barunya sebagai ibu ${ }^{7}$. Oleh karena itu, risiko ibu hamil merasa cemas baik itu cemas akan keselamatan dirinya maupun keselamatan calon bayinya akan meningkat. Menurut Huizink, pada ibu hamil dapat terjadi 3 bentuk kecemasan yaitu rasa takut terhadap melahirkan, takut melahirkan anak yang cacat baik secara psikologis maupun secara fisik, dan juga takut terhadap pandangan orang lain ${ }^{8}$.

Penelitian di Indonesia menunjukkan bahwa ibu hamil yang mengalami kecemasan pada masa kehamilannya memiliki risiko tinggi mengalami kelahiran prematur dan bahkan meningkatkan angka kematian bayi (AKB). Kecemasan pada masa kehamilan juga dapat menyebabkan peningkatan angka kematian ibu $(\mathrm{AKI})^{9}$. Dalam sebuah penelitian yang dilakukan pada ibu hamil primigravida trimester tiga di Puskesmas Sonder, ditemukan sebanyak $76,7 \%$ ibu hamil mengalami kecemasan sedang ${ }^{10}$.

Gangguan tidur merupakan salah satu masalah dalam kesehatan masyakarat. Gangguan tidur baik itu durasi tidur yang tidak mencukupi maupun kualitas tidur yang buruk sangat sering terjadi pada ibu hamil ${ }^{11}$. Kualitas tidur buruk merupakan penurunan kualitas tidur yang dapat berupa meningkatnya frekuensi terbangun di malam hari atau sulitnya untuk memulai (inisiasi) tidur ${ }^{12,13}$. Kualitas tidur buruk pada ibu hamil dapat menyebabkan ibu hamil mengalami kehamilan risiko tinggi, seperti gangguan pertumbuhan janin dan depresi postpartum ${ }^{14}$. Pada penelitian systematic review yang dilakukan oleh Gultom dan Kamsatun, ditemukan sebanyak $56,5 \%$ ibu hamil trimester tiga mengalami kualitas tidur yang buruk ${ }^{15}$.

Dalam sebuah penelitian di UPT Puskesmas Kecamatan Cimanggis dan Sukmajaya, ditemukan ibu hamil trimester tiga yang mengalami kecemasan tingkat sedang hingga berat memiliki kualitas tidur yang buruk, yaitu sebanyak 95,3\%, pada penelitian ini dinyatakan bahwa terdapat korelasi antara tingkat kecemasan terhadap kualitas tidur pada ibu hamil ${ }^{7}$. Akan tetapi, pada penelitian yang dilakukan oleh Palifiana dan Wulandari, tidak ditemukan adanya hubungan yang berarti antara kecemasan dengan kualitas tidur ibu hamil trimester tiga di klinik Pratama Asih Waluyo Jati ${ }^{16}$. 
Berdasarkan permasalahan di atas dan adanya perbedaan antara data dari kedua penelitian tersebut, peneliti tertarik untuk meneliti pengaruh kecemasan terhadap kualitas tidur ibu hamil trimester ketiga di wilayah kerja Puskesmas Tanjung Karang Mataram. Penelitian ini merupakan penelitian yang pertama kali dilakukan di Provinsi Nusa Tenggara Barat.

\section{METODE}

Penelitian ini menggunakan desain penelitian deskriptif analitik dengan pendekatan cross sectional untuk mengetahui pengaruh tingkat kecemasan terhadap kualitas tidur ibu hamil trimester tiga. Data penelitian diambil menggunakan kuesioner Hamilton Anxiety Rating Scale (HARS) untuk mengukur tingkat kecemasan dan kuesioner Pittsburgh Sleep Quality Index (PSQI) untuk mengukur kualitas tidur. Pengambilan dan pengolahan data dilakukan pada bulan Mei hingga Juli 2021.

Sampel dalam penelitian ini adalah wanita hamil trimester tiga yang melakukan pemeriksaan di Puskesmas Tanjung Karang Mataram pada bulan April hingga Mei 2021. Penelitian ini menggunakan teknik sampling consecutive sampling, yaitu dengan cara mengambil setiap sampel yang memenuhi kriteria penelitian pada kurun waktu tertentu hingga jumlah sampel minimal dapat terpenuhi. Kriteria inklusi pada penelitian ini adalah wanita hamil trimester ketiga (usia kandungan $\geq 28$ minggu) yang berpendidikan minimal SD dan bersedia menjadi responden. Kriteria eksklusi penelitian ini adalah wanita hamil yang pernah didiagnosis mengalami gangguan psikiatri (sebelumnya telah mengkonsumsi obat psikiatri selama 6 minggu atau berobat ke poli jiwa dan didiagnosis mengalami gangguan psikiatri) serta wanita hamil yang telah terdiagnosa mengalami gangguan pernapasan saat tidur (SDB) dan/atau sindrom kaki gelisah (RLS) pada kehamilan saat ini.

Variabel bebas (independent variable) dalam penelitian ini adalah kecemasan pada kehamilan. Varibel terikat (dependent variable) dalam penelitian ini adalah kualitas tidur buruk pada kehamilan. Adapun variabel perancu pada penelitian ini adalah hal yang dapat mempengaruhi kualitas tidur (perubahan anatomi, perubahan fisiologi, perubahan hormonal) serta penyebab lain dari gangguan tidur [Gangguan Pernapasan saat Tidur (SDB) dan Sindrom Kaki Gelisah (RLS)].

Pada penelitian ini pengolahan data dilakukan menggunakan aplikasi analisis statistik SPSS versi 24. Uji korelasi yang digunakan adalah uji korelasi non-parametrik Spearman.

\section{HASIL DAN PEMBAHASAN}

\section{Hasil}

Penelitian ini dilakukan di Puskesmas Tanjung Karang Kota Mataram sejak tanggal 3 Mei 2021 hingga 22 Mei 2021. Jumlah responden dalam penelitian ini adalah sebanyak 32 orang yang memenuhi kriteria inklusi penelitian. Adapun karakteristik subjek penelitian dapat dilihat pada Tabel 1 .

Tabel 1. Karakteristik Responden berdasarkan Usia, Tingkat Pendidikan, Pekerjaan, dan Paritas.

\begin{tabular}{llcc}
\hline \multirow{2}{*}{ Kategori } & \multicolumn{1}{c}{ Sub-kategori } & Frequency & Percent \\
\hline Usia & Usia $<20$ tahun & 1 & 3.1 \\
\cline { 2 - 4 } & Usia 20 hingga 35 tahun & 28 & 87.5 \\
\hline
\end{tabular}




\begin{tabular}{llll}
\hline & Usia >35 tahun & 3 & 9.4 \\
\hline Tingkat Pendidikan & SD & 7 & 21.9 \\
\cline { 2 - 4 } & SMP & 5 & 15.6 \\
\cline { 2 - 4 } & SMA & 12 & 37.5 \\
\cline { 2 - 4 } & Pendidikan Tinggi & 8 & 25.0 \\
\hline Pekerjaan & Bekerja & 6 & 18.8 \\
\cline { 2 - 4 } & Tidak Bekerja & 26 & 81.3 \\
\hline Paritas & Primigravida & 11 & 34.4 \\
\cline { 2 - 4 } & Multigravida & 21 & 65.6 \\
\hline
\end{tabular}

SD= Sekolah Dasar; SMP = Sekolah Menengah Pertama; SMA = Sekolah Menengah Atas

Mayoritas ibu hamil pada penelitian ini berusia 20 hingga 35 tahun (87.5\%). Rata-rata ibu hamil berpendidikan tinggi (62.5\%). Terdapat 26 ibu hamil yang tidak bekerja $(81.3 \%)$ dan 21 ibu hamil yang merupakan multigravida (65.6\%). Mayoritas ibu hamil mengalami tingkat kecemasan ringan $(62.5 \%)$, sedangkan untuk sisanya mengalami tingkat kecemasan sedang (21.9\%) dan tingkat kecemasan berat (15.6\%). Mayoritas ibu hamil memiliki kualitas tidur buruk (53.1\%). Adapun tingkat kecemasan dan kualitas tidur subjek penelitian dapat dilihat pada Tabel 2 dan Tabel 3.

Tabel 2. Tingkat Kecemasan

\begin{tabular}{lccc}
\hline Kategori & Subkategori & Frequency & Percent \\
\hline Tingkat Kecemasan & Kecemasan Ringan & 20 & 62.5 \\
& Kecemasan Sedang & 7 & 21.9 \\
& Kecemasan Berat & 5 & 15.6 \\
Total & & 32 & 100.0 \\
\hline
\end{tabular}

Tabel 3. Kualitas Tidur

\begin{tabular}{lccc}
\hline \multicolumn{1}{c}{ Kategori } & Subkategori & Frequency & Percent \\
\hline Kualitas Tidur & Baik & 15 & 46.9 \\
& & & \\
& Buruk & 17 & 53.1 \\
Total & & 32 & 100.0 \\
\hline
\end{tabular}

Penelitian ini bertujuan untuk mengetahui pengaruh tingkat kecemasan terhadap kualitas tidur ibu hamil. Korelasi antar variabel ditentukan dengan melakukan uji statistik Spearman. Adapun hasil uji Crosstab Tingkat Kecemasan dan Kualitas Tidur dapat dilihat pada Tabel 4. 
Tabel 4. Crosstab Tingkat Kecemasan * Kualitas Tidur

\begin{tabular}{lcccc}
\hline & & \multicolumn{2}{c}{ Kualitas Tidur } & Total \\
& & Baik & Buruk & \\
\hline Tingkat Kecemasan & Kecemasan Ringan & 15 & 5 & 20 \\
& & $46.9 \%$ & $15.6 \%$ & $62.5 \%$ \\
& Kecemasan Sedang & 0 & 7 & 7 \\
& & $0.0 \%$ & $21.9 \%$ & $21.9 \%$ \\
& Kecemasan Berat & 0 & 5 & 5 \\
Total & & $0.0 \%$ & $15.6 \%$ & $15.6 \%$ \\
& & $46.9 \%$ & $53.1 \%$ & $100.0 \%$ \\
\hline
\end{tabular}

Tabel 5. Hasil Analisis Korelasi Spearman

\begin{tabular}{ll}
\hline & \multicolumn{1}{c}{ Kualitas Tidur } \\
\hline Tingkat Kecemasan & $\mathrm{r}=0.731$ \\
& $\mathrm{p}<0,001$ \\
& $\mathrm{n}=32$ \\
\hline
\end{tabular}

Uji bivariat pada penelitian ini menggunakan uji korelasi Spearman dengan sebelumnya telah dilakukan uji distribusi dan didapatkan distribusi kedua variabel tidak normal dengan nilai $\mathrm{p}<0.001$ ( $\mathrm{p}$ value $<0.05$ ). Dari tabel Hasil Analisis Korelasi Spearman di atas, diperoleh nilai $\mathrm{p}$ sebesar < 0,001 ( $\mathrm{p}$ value < 0.05) yang menunjukkan adanya korelasi yang bermakna antara tingkat kecemasan dan kualitas tidur pada ibu hamil trimester tiga. Nilai koefisien korelasi Spearman (r) sebesar 0.731 menunjukkan korelasi positif dengan kekuatan korelasi yang kuat.

\section{Pembahasan}

Pada rentang usia 20 hingga 35 tahun, wanita berada pada kondisi terbaik untuk hamil karena, secara fisik, uterus telah siap untuk mengandung. Secara psikologis, wanita telah siap untuk merawat kehamilan dan kelak dapat merawat anaknya ${ }^{17}$. Berdasarkan penelitian yang dilakukan oleh Mariyona, kehamilan pada usia di bawah 20 tahun dapat memicu beberapa komplikasi, seperti kelahiran prematur, perdarahan sebelum dan sesudah bayi lahir, berat bayi lahir rendah (BBLR), dan retardasi mental. Jika wanita hamil di usia lebih dari 35 tahun, wanita tersebut memiliki risiko mengalami perdarahan di awal kehamilan dan dapat mengalami anemia 18

Jika tingkat pendidikannya tinggi, seseorang akan mencari informasi dan pengobatan ke tempat pelayanan kesehatan. Di sisi lain, apabila tingkat pendidikannya rendah, seseorang dapat merasa cemas akibat dari kurangnya informasi yang diterima ${ }^{19}$. Pada penelitian yang dilakukan oleh Kotimaki, ditemukan bahwa ibu hamil yang memiliki tingkat pendidikan tinggi cenderung memiliki tingkat kecemasan yang rendah ${ }^{20}$.

Ibu hamil yang memiliki pekerjaan cenderung merasa cemas kehilangan pekerjaannya apabila dia tidak dapat menyelesaikan pekerjaanya akibat dari kehamilannya. Akan tetapi, jika pekerjaannya tidak terlalu berat dan ibu hamil dapat mengatasinya, pekerjaan tersebut dapat memberikan dampak positif terhadap kehamilannya, seperti mengalihkan kecemasan yang datang dari kehamilan tersebut ${ }^{21}$.

Kecemasan akibat tingkat paritas berhubungan dengan pengalaman persalinan ibu hamil dan kelak akan berpengaruh pada kesiapannya untuk melahirkan. Tingginya kecemasan ibu hamil 
dapat dipengaruhi oleh kejadian pada kehamilan sebelumnya, seperti abortus dan pengalaman persalinan sebelumnya ${ }^{22}$.

Pada kehamilan, khususnya trimester ketiga, terjadi peningkatan aktivitas sistem saraf simpatis yang sebagian besar dipengaruhi oleh perubahan hormonal. Hal ini akan menyebabkan peningkatan cardiac load dan fraksi ejeksi jantung sehingga ibu hamil akan cepat lelah. Waktu digesti akan melambat, diikuti dengan waktu pengosongan lambung yang meningkat sehingga dapat menyebabkan konstipasi pada ibu hamil. Bertambahnya volume uterus juga dapat menyebabkan gangguan reflux gastroesophageal (GERD) yang disebabkan oleh uterus menekan lambung sehingga menyebabkan makanan kembali naik ke esofagus ${ }^{13,16}$.

Penelitian ini telah sesuai dengan teori yang dikemukakan oleh Janiwarty dan Pieter pada tahun 2013, yaitu pada trimester tiga, perubahan psikologis ibu akan semakin meningkat dibandingkan trimester sebelumnya. Peristiwa ini disebabkan oleh usia kehamilan yang semakin membesar. Perubahan psikologis yang terjadi pada trimester tiga, antara lain: gangguan tidur, perubahan kondisi emosional, dan rasa tidak nyaman. Perubahan emosi ini akan menyebabkan timbulnya rasa cemas, rasa takut, rasa tidak nyaman, rasa khawatir, bimbang dan ragu pada kehamilannya $^{23}$. Selain itu, kecemasan pada ibu hamil dapat disebabkan oleh kemungkinan bayi mengalami gangguan pertumbuhan dan perkembangan, bayi tidak dapat bernapas secara spontan, terjadinya trauma vaginal dan perianal pada proses persalinan, kemampuannya untuk menjadi ibu yang baik, kesuksesan untuk inisiasi menyusui dini, dan perubahan postur tubuh selama kehamilannya ${ }^{3}$.

Penelitian ini juga sesuai dengan penelitian yang dilakukan oleh Maimunah, dimana terdapat $57.8 \%$ ibu hamil di trimester ketiga mengalami kecemasan yang berkaitan dengan proses persalinan. Ibu hamil merasa cemas dengan proses persalinannya karena persalinan merupakan tahap terakhir dari kehamilan, ibu hamil harus berjuang untuk melahirkan bayinya dengan kemampuannya sendiri, atau ibu hamil merasa cemas apabila persalinannya memerlukan bantuan alat atau bahkan harus menjalani operasi. Selain itu, pada penelitian ini, ibu hamil juga merasa cemas apakah bayinya akan terlahir cacat, kembar, atau prematur ${ }^{24}$.

Penelitian ini sesuai dengan penelitian yang telah dilakukan oleh Wintoro, Rohmawati, dan Sulistyowati pada tahun 2019 yang menemukan sebanyak 90\% ibu hamil trimester tiga memiliki kualitas tidur yang buruk ${ }^{1}$. Perubahan fisik, seperti bertambahnya berat badan dan tekanan akibat perkembangan janin pada trimester tiga, akan sangat berpengaruh terhadap kualitas tidur. Beberapa masalah pada trimester tiga yang dapat menyebabkan kualitas tidur yang buruk adalah nyeri punggung, depresi, cemas, insomnia, mendengkur, sleep apnea, kram kaki, dan restless legs syndrome. Kualitas tidur yang buruk dapat memicu komplikasi pada saat melahirkan seperti preeklamsia dan bayi lahir prematur. Wanita hamil yang memiliki insomnia atau mendengkur berisiko melahirkan bayi yang terlalu besar atau terlalu kecil. Wanita yang mengalami gangguan tidur pada akhir kehamilannya beresiko memiliki waktu persalinan yang lebih lama dan memiliki risiko lebih tinggi untuk bedah sesar ${ }^{25}$.

Pada hasil penelitian ini, didapatkan nilai $\mathrm{p}<0.001$, yaitu kurang dari taraf signifikansi yang digunakan $5 \%(0,000<0,05)$ sehingga HA diterima dan disimpulkan bahwa kecemasan berpengaruh terhadap kualitas tidur ibu hamil trimester tiga di puskesmas Tanjung Karang Mataram. Koefisien korelasi pada penelitian ini adalah 0.731 (mendekati +1 ) sehingga menunjukkan korelasi positif dengan kekuatan korelasi yang kuat antara kecemasan dan kualitas tidur ibu hamil trimester tiga, yaitu semakin tinggi tingkat kecemasan ibu hamil maka kualitas tidurnya akan semakin buruk. 
Penelitian ini sesuai dengan penelitian yang dilakukan oleh Wardani, Agustina, dan Astika yang menyatakan adanya korelasi antara tingkat kecemasan dengan kualitas tidur ibu hamil primigravida trimester tiga di RSUD Idaman Banjarbaru ${ }^{2}$. Penelitian ini juga sesuai dengan penelitian yang dilakukan oleh Wintoro, Rohmawati, dan Sulistyowati yang menyatakan adanya korelasi yang signifikan antara tingkat kecemasan dengan kualitas tidur ibu hamil trimester tiga di BPM Siti Sujalmi Socokangsi Jatinom ${ }^{1}$. Selain itu, penelitian ini juga sesuai dengan penelitian yang dilakukan oleh Shariat et al, yaitu terdapat korelasi yang signifikan antara kualitas tidur dan gangguan psikiatri. Pada penelitian ini, semakin tinggi tingkat kecemasan maka kualitas tidur ibu hamil akan semakin rendah ${ }^{26}$.

Kondisi terjaga disebabkan oleh aktifnya ascending arousal system. Neurotransmitter yang berperan pada sistem ini adalah noradrenergik, serotonin, histamin, dopamin, dan asetilkolin. Untuk inisiasi tidur, ascending arousal system akan diinaktivasi oleh neurotransmitter inhibitor, seperti gamma amino-butyric acid (GABA). GABA berasal dari daerah ventrolateral preoptic area (VLPO). Modulasi dari siklus rapid eye movement (REM) dan non-rapid eye movement (NREM) akan diatur oleh inhibisi resiprokal antara neuron kolinergik dan batang otak. Pada fase REM, neuron kolinergik akan menjadi aktif sedangkan neuron noradrenergik dan serotonergik akan terinhibisi dan berlaku sebaliknya pada fase NREM ${ }^{13,27}$.

Peningkatan noradrenergik akibat stimulasi sistem saraf simpatis pada saat seseorang merasa cemas akan menyebabkan berkurangnya siklus REM karena neuron noradrenergik akan semakin aktif dan sulit untuk diinhibisi sehingga seseorang cenderung lebih sering terjaga di malam hari dan memiliki kualitas tidur yang buruk ${ }^{28}$. Selain itu, ketika merasa cemas kadar neurotransmitter GABA akan menurun sehingga seseorang akan kesulitan untuk menginisiasi tidur karena kurangnya neurotransmitter untuk menginhibisi ascending arousal system ${ }^{29}$.

Berdasarkan hasil analisis pengaruh tingkat kecemasan dengan kualitas tidur ibu hamil trimester tiga di Puskesmas Tanjung Karang Mataram, didapatkan hasil responden dengan kecemasan ringan yang memilki kualitas tidur baik sebanyak 15 orang (46.9\%). Hal ini dapat terjadi pada ibu hamil yang telah merasa siap untuk menghadapi kehamilannya, seperti telah menyiapkan anggaran untuk proses persalinan, mengkonsumsi makanan yang bergizi, mendapat dukungan dari suami dan keluarga, serta memiliki pengetahuan yang cukup terkait kondisinya dan janin yang dikandung ${ }^{21}$.

Hasil analisis pengaruh tingkat kecemasan dengan kualitas tidur ibu hamil trimester tiga di Puskesmas Tanjung Karang Mataram didapatkan hasil responden dengan kecemasan ringan yang memiliki kualitas tidur baik sebanyak 15 orang (46.9\%). Hal ini dapat disebabkan rasa tidak nyaman akibat lingkungan tidurnya, baik itu disebabkan suara bising, kualitas udara yang buruk, atau cahaya yang terlalu terang ${ }^{30}$.

Ibu hamil yang memiliki tingkat kecemasan sedang (21.9\%) dan kecemasan berat (15.6\%) secara keseluruhan memiliki kualitas tidur yang buruk. Ibu hamil trimester tiga sering kali memikirkan proses persalinan serta memikirkan kondisi bayinya setelah lahir nanti. Hal ini menyebabkan ibu hamil merasa cemas. Perasaan cemas ini menyebabkan ibu hamil kesulitan untuk memulai tidur atau bahkan sering terjaga di malam hari sehingga dapat menurunkan kualitas tidur ${ }^{1}$. Selain kecemasan, ibu hamil trimester tiga di Puskesmas Tanjung Karang juga mengeluhkan terbangun di malam hari akibat sering buang air kecil, rasa tidak nyaman di punggung, dan kram di kaki.

Salah satu keterbatasan penelitian ini adalah variabel perancu, seperti perubahan anatomis serta fisiologis pada kehamilan. Selain itu, terdapat beberapa responden yang 
mengeluhkan terbangun di malam hari karena ingin buang air kecil, merasa pegal di punggung, kram di kaki, dan sesak napas.

\section{KESIMPULAN}

Berdasarkan penelitian yang telah dilakukan di Puskesmas Tanjung Karang Mataram dengan judul Pengaruh Tingkat Kecemasan terhadap Kualitas Tidur Ibu Hamil Trimester Tiga, dapat ditarik kesimpulan sebagai berikut:

1. Kecemasan berpengaruh terhadap kualitas tidur ibu hamil trimester tiga di Puskesmas Tanjung Karang Mataram. Semakin tinggi tingkat kecemasan ibu hamil maka kualitas tidurnya akan semakin memburuk.

2. Pada penelitian ini, mayoritas responden berusia cukup. Untuk tingkat pendidikan, mayoritas responden memiliki tingkat pendidikan tinggi. Responden pada penelitian ini sebagian besar tidak bekerja. Sedangkan untuk riwayat kehamilan, sebagian besar responden merupakan multigravida.

3. Pada penelitian ini, mayoritas ibu hamil mengalami kecemasan ringan, yaitu sebanyak 20 orang, dan 15 orang tersebut memiliki kualitas tidur yang baik sedangkan 5 orang lainnya memiliki kualitas tidur yang buruk..

4. Ibu hamil yang memiliki tingkat kecemasan sedang dan berat memiliki kualitas tidur yang buruk secara keseluruhan.

\section{UCAPAN TERIMA KASIH}

Penulis mengucapkan terima kasih kepada dr. Agustine Mahardika, M. Kes., Sp. KJ dan dr. M. Rizkinov Jumsa, Sp. OG., M. Kes. yang telah bersedia meluangkan waktu untuk memberikan bimbingan dan arahan serta memberikan semangat dan saran kepada penulis selama proses penelitian. Penulis juga mengucapkan terima kasih kepada kedua orang tua, kedua kakak, serta teman teman penulis yang selalu menyemangati penulis selama proses penelitian.

\section{DAFTAR PUSTAKA}

1. Wintoro PD, Rohmawati W, Sulistyowati A. Hubungan tingkat kecemasan dengan kualitas tidur pada ibu hamil trimester III di Socokangsi Jatinom Klaten. J Ris Kebidanan Indones. 2019;3(1):27-32.

2. Wardani HW, Agustina R, Damayanti EAF. Tingkat Kecemasan dengan Kualitas Tidur Ibu Hamil Primigravida Trimester III. Dunia Keperawatan. 2018;6(1):1.

3. Deklava L, Lubina K, Circenis K, Sudraba V, Millere I. Causes of Anxiety during Pregnancy. Procedia - Soc Behav Sci [Internet]. 2015;205(May):623-6. Available from: http://dx.doi.org/10.1016/j.sbspro.2015.09.097

4. Bystritsky A, Khalsa SS, Cameron ME, Schiffman J. Current diagnosis and treatment of anxiety disorders. P T. 2013;38(1).

5. Adwas AA, Jbireal JM, Azab AE. Anxiety: Insights into Signs, Symptoms, Etiology, Pathophysiology, and Treatment. East African Sch J Med Sci. 2019;2(October):80-91.

6. Biaggi A, Conroy S, Pawlby S, Pariante CM. Identifying the women at risk of antenatal anxiety and depression: A systematic review [Internet]. Vol. 191, Journal of Affective Disorders. Elsevier B.V.; 2016 [cited 2021 Feb 3]. p. 62-77. Available from: /pmc/articles/PMC4879174/?report=abstract

7. Rahmawati D, Ungsianik T. Anxiety, Depression, and Sleep Quality of Third Trimester Pregnant Women. UI Proc Heal Med [Internet]. 2017;1. Available from: http://proceedings.ui.ac.id/index.php/uiphm/article/download/153/197 
8. Ardilah NW, Setyaningsih W, Narulita S, Keperawatan PS, Binawan U. Pengaruh Tingkat Kecemasan Ibu Hamil Trimester Iii Effect of Anxiety Levels on Third-Trimester. 2019;1:148-53.

9. Siallagan D, Lestari D. Tingkat Kecemasan Menghadapi Persalinan Berdasarkan Status Kesehatan, Graviditas Dan Usia Di Wilayah Kerja Puskesmas Jombang. Indones J Midwifery. 2018;1(2):10410.

10. Menajang NK, Pondaag L, Kundre R. Hubungan Dukungan Suami Dengan Tingkat Kecemasan Pada Ibu Primigravida Trimester III Di Puskesmas Sonder. e-journal Keperawatan. 2017;5(1).

11. Hutchison BL, Stone PR, McCowan LME, Stewart AW, Thompson JMD, Mitchell EA. A postal survey of maternal sleep in late pregnancy. BMC Pregnancy Childbirth [Internet]. 2012 Dec 10 [cited 2021 Feb 3];12(1):144. Available from: https://bmcpregnancychildbirth.biomedcentral.com/articles/10.1186/1471-2393-12-144

12. Rezaei E, Moghadam ZB, Saraylu K. Quality of life in pregnant women with sleep disorder. J Fam Reprod Heal. 2013;7(2).

13. Silvestri R, Aricò I. Sleep disorders in pregnancy. In: Sleep Science. 2019.

14. Xu X, Liu D, Zhang Z, Sharma M, Zhao Y. Sleep duration and quality in pregnant women: A crosssectional survey in China. Int J Environ Res Public Health [Internet]. 2017 Jul 20 [cited 2021 Feb 3];14(7). Available from:/pmc/articles/PMC5551255/?report=abstract

15. Gultom DOV, Kamsatun. Gambaran Kualitas Tidur Ibu Hamil Trimester Iii : Studi Literatur. J Kesehat Siliwangi. 2020;1(1):25-33.

16. Palifiana DA, Wulandari S. Analisis Faktor Dominan Yang Mempengaruhi Kualitas Tidur Ibu Hamil Trimester III di Klinik Pratama Asih Waluyo Jati. J Kebidanan Indones [Internet]. 2018;9(2):1-14. Available from: https://jurnal.stikesmus.ac.id/index.php/JKebIn/article/view/203/159

17. Alibasjah RW, Izza K, Susiloningsih N. Hubungan Usia Ibu Hamil Trimester 3 Dengan Kecemasan Menghadapi Persalinan Pada Primigravida Di Wilayah Kerja Puskesmas Palimanan Cirebon. Fak Kedokt Diponegoro. 2016;19-26.

18. Mariyona K. Komplikasi dan Faktor Resiko Kehamilan di Puskesmas. J Menara Med. 2019;1(2):10916.

19. Sukaedah E, Fadilah L. Hubungan Tingkat Pendidikan dan Dukungan Suami dengan Tingkat Kecemasan Ibu Primigravida Trimester III. Medikes. 2016;3(1):56-62.

20. Kotimäki S, Härkönen J, Karlsson L, Karlsson H, Scheinin NM. Educational differences in prenatal anxiety and depressive symptoms and the role of childhood circumstances. SSM - Popul Heal. $2020 ; 12$.

21. Said N, Kanine E, Bidjuni H. Hubungan Faktor Sosial Ekonomi Dengan Kecemasan Ibu Primigravida Di Puskesmastuminting. J Keperawatan UNSRAT. 2015;3(2):111622.

22. Fajrin FI. Hubungan Paritas Dengan Tingkat Kecemasan Ibu Hamil Trimester III Dalam Menghadapi Persalinan (Di BPS Subiyana, Amd.Keb Desa Parengan Kecamatan Maduran Kabupaten Lamongan). Kebidanan Univ Islam Lamongan. 2017;4:9-15.

23. Janiwarty B, Pieter HZ. Pendidikan Psikologi Untuk Bidan: Suatu Teori dan Terapannya. Cet 1. Hardjono D, editor. Yogyakarta: Rapha Publishing; 2013.

24. Maimunah S. Kecemasan Ibu Hamil Menjelang Persalinan Pertama. J Humanit. 2012;5(1):11516.

25. Taskiran N. Pregnancy and Sleep Quality. J Turkish Soc Obstet Gynecol. 2011;8(3):181-7.

26. Shariat M, Abedinia N, Noorbala AA, Raznahan M. The relationship between sleep quality, depression, and anxiety in pregnant women: A cohort ctudy. J Sleep Sci [Internet]. 2017;2(1):20-7. Available from: http://jss.tums.ac.ir/index.php/jss/article/view/51

27. Carley DW, Farabi SS. Physiology of sleep. Diabetes Spectr. 2016;29(1):5-9.

28. Mehta R, Singh A, Mallick BN. Disciplined sleep for healthy living: Role of noradrenaline. World J 
Neurol. 2017;7(1):6.

29. Stahl SM. Stahl's Essential Psychopharmacology. Fourth Edi. Angewandte Chemie International Edition, 6(11), 951-952. Cambridge: Cambridge University Press; 2013.

30. Altun I, Cinar N, Dede C. The contributing factors to poor sleep experiences in according to the university students: A cross-sectional study. J Res Med Sci [Internet]. 2012 Apr [cited $2021 \mathrm{Feb}$ 5];17(6):557-61. Available from:/pmc/articles/PMC3634295/?report=abstract 